\title{
Publishing Survey Research
}

\author{
Samuel J. Stratton, MD, MPH
}

Should research based on survey methodology be published in Prehospital and Disaster Medicine? Surveys are a common research methodology for papers submitted to the Journal. This may be because data for surveys can be collected relatively easily using the telephone, the Internet, direct mailing, group distribution, and interviews. Obtaining data for other methods of prehospital and disaster research is more difficult than for most survey formats.

Unfortunately, survey research is prone to bias and error. Survey questions can be worded in such a way that the researcher's opinions and biases are exposed to the persons completing the survey. Exposed researcher bias can influence survey response.

Survey questions should be designed to limit internal and external bias. It is standard to pre-test survey questions with a study population test group before conducting the actual study survey. Pre-testing survey questions helps identify poorly worded questions, and provides for potential identification of some types of bias.

Response rate and sample size are important elements of valid surveys. A frequent problem with surveys is poor response rates, which can cause selection bias. Selection bias is inherent with surveys because those who respond to questions are a distinct subgroup of a total survey population. Predicting response rates is difficult, but estimates can be made based on survey technique (such as Internet or interview) and the study population. Prior to conducting a survey, it is standard to determine how large a sample of the study population is needed for valid conclusions. However, unless an entire population is surveyed (a census), there is always risk for error. A large sample of a study population decreases the risk for unacceptable error in results. In reporting survey results, it is appropriate to report an estimate of the margin of error for the results.

When conducting surveys, a researcher must take all possible actions to avoid bias and error. Common forms of survey bias are listed in Table 1, along with suggested actions to avoid each type of bias.

In summary, surveys are prone to error and bias. Valid results and conclusions require adherence to good survey research techniques, some of which have been described in this editorial. While Prehospital and Disaster Medicine will continue to accept for review manuscripts based on survey methodology, only those studies which limit risk of bias and error will be published.

\begin{tabular}{|c|c|}
\hline Potential Bias Source & Suggested Action \\
\hline $\begin{array}{l}\text { 1. Researcher bias exposed, } \\
\text { resulting in subjects } \\
\text { answering questions to } \\
\text { please or argue with the } \\
\text { researcher }\end{array}$ & $\begin{array}{l}\text { 1. Pre-test survey questions; } \\
\text { have questions reviewed by } \\
\text { non-involved research } \\
\text { expert(s) to detect bias }\end{array}$ \\
\hline $\begin{array}{l}\text { 2. Survey subjects unable to } \\
\text { understand questions; } \\
\text { questions poorly stated and } \\
\text { unclear }\end{array}$ & $\begin{array}{l}\text { 2. Pre-test survey questions; } \\
\text { match language level of } \\
\text { survey with that of study } \\
\text { population }\end{array}$ \\
\hline $\begin{array}{l}\text { 3. Unrecognized external bias } \\
\text { from news reports, } \\
\text { community information, or } \\
\text { political concerns }\end{array}$ & $\begin{array}{l}\text { 3. Include survey questions } \\
\text { designed to determine } \\
\text { whether external bias is } \\
\text { present }\end{array}$ \\
\hline $\begin{array}{l}\text { 4. Failure to select the survey } \\
\text { group such that the whole } \\
\text { population is represented; } \\
\text { selection bias; poor selection } \\
\text { of participants }\end{array}$ & $\begin{array}{l}\text { 4. Select survey subjects to } \\
\text { match the demographic } \\
\text { and experience } \\
\text { characteristics of the study } \\
\text { population. Use an } \\
\text { appropriate sample size. }\end{array}$ \\
\hline $\begin{array}{l}\text { 5. Situational bias; situation too } \\
\text { distant in past for unbiased } \\
\text { recall to answer questions }\end{array}$ & $\begin{array}{l}\text { 5. Conduct survey concurrent } \\
\text { with or as soon as possible } \\
\text { after an event }\end{array}$ \\
\hline 6. Inadequate survey sample & $\begin{array}{l}\text { 6. Prior to conducting survey, } \\
\text { determine the number of } \\
\text { participants needed using } \\
\text { standard statistical methods } \\
\text { based on acceptable error of } \\
\text { results and expected } \\
\text { response rate }\end{array}$ \\
\hline 7. Effect of non-responders & $\begin{array}{l}\text { 7. Calculate and report } \\
\text { estimated margin of error } \\
\text { for results }\end{array}$ \\
\hline
\end{tabular}

Table 1. Common Forms of Survey Bias and Error, and Suggested Actions to Avoid Them

doi:10.1017/S1049023X1200115X 